IRSTI 85.15.09; 39.21.02

\author{
${ }^{1}$ Nyussupova G.N., ${ }^{1}$ Isolde Brade, ${ }^{3}$ Kairova S.G., ${ }^{1 *}$ Kenespayeva L.B. \\ ${ }^{1 *}$ Department of Geography, Land Management and Cadastre, Al-Farabi Kazakh National University, \\ Kazakhstan, Almaty, laura.kenespaeva81@gmail.com \\ ${ }^{2}$ Department of Regional Geography of Europe, Leibniz Institute for Regional Geography, Germany, Leipzig, \\ ${ }^{3}$ S. Toraigyrov Pavlodar State University, Kazakhstan, Pavlodar,
}

\title{
SOCIAL INDICATORS OF THE QUALITY OF LIFE OF THE POPULATION OF THE REPUBLIC OF KAZAKHSTAN: ANALYSIS AND EVALUATION
}

Indicators of level and quality of life are intended to reflect the degree of social and economic relations in the country. The modern state can develop only under the condition that its economic and social policy has as its reference point the level of growth and quality of life. This article reflects the social indicators of the quality of life of the population of the Republic of Kazakhstan. The main key indicators of the social block of the quality of life of the population were determined, the calculation of integral indices was carried out, on the basis of which the typology of the regions of Kazakhstan on the social block of the level of quality of life of the population was carried out. The social block of indicators of the quality of life of the population in the regions of Kazakhstan is presented by statistical data in the dynamics on such sub-blocks as education; science and innovation; health care; culture; security; living conditions; social infrastructure; social security, leisure and recreation. The key indicators characterizing the quality of the population's life in the social unit are: the cumulative education enrollment rate for the population aged 6-24; index of real incomes of the population; physicians per 10000 people; housing provision of the population; the number of recipients of state social benefits. These key social indicators reflect the social well-being of the population in the regions.

Key words: Republic of Kazakhstan, quality of life of the population, social indicators, typology of regions, key indicators.

${ }^{1}$ Нүсіпова Г.Н., ${ }^{2}$ Браде И., ${ }^{3}$ Каирова Ш.Ғ., ${ }^{1 *}$ Кенеспаева А.Б.

${ }^{1} \wedge$ ейбниц атындағы аймақтық, география институты, Германия, Аейпциг қ.,

2аға оқытушы, С.Торайғыров атындағы Павлодар мемлекеттік университеті, Қазақстан, Павлодар қ.,

3əл-Фараби атындағы Қазақ, ұлттық, университеті, Қазақстан, Алматы қ., e-mail: laura.kenespaeva81@gmail.com

\section{Қазақстан Республикасы өмір сүру сапасының} әлеуметтік көрсеткіштері: та^дау және бағалау

\footnotetext{
Халықтың өмір сүру деңгейі мен сапасының көрсеткіші елдегі әлеуметтік-экономикалық қатынастардың даму деңгейін көрсетуге арналған. Қазіргі заманғы мемлекет әлеуметтікэкономикалық саясаттың азаматтардың өмір сүру деңгейі мен сапасын көтергенде ғана дами алады. Бұл мақала Қазақстан халқының өмір сүру сапасының әлеуметтік көрсеткіштерін көрсетеді: халықтың өмір сүру сапасының әлеуметтік блогының негізгі көрсеткіштері айқындалды, Қазақстанның аймақтарының типологиясы халықтың өмір сүру сапасы деңгейінің әлеуметтік блогында жүргізілді, интегралдық индекстерді есептеу жүргізілді. Қазақстанның өңірлерінде халықтың өмір сүру сапасының индикаторларының әлеуметтік блогы динамикада білім ретінде осындай қосалқы блок бойынша статистикалық деректермен ұсынылған; ғылым мен инновациялар; денсаулық сақтау; мәдениет; қауіпсіздік; тұрғын үй жағдайлары; әлеуметтік инфрақұрылым; әлеуметтік қамсыздандыру және демалыс. Әлеуметтік бірліктегі халықтың өмір сүру сапасын сипаттайтын негізгі көрсеткіштер: 6-24 жас аралығындағы халықтың білім деңгейі; халықтың нақты табысының индексі; дәрігерлермен қамтамасыз ету; тұрғындарды тұрғын үймен
} 
қамтамасыз ету; мемлекеттік әлеуметтік жәрдемақылар алушылар саны. Бұл негізгі әлеуметтік көрсеткіштер өңірлердегі халықтың әлеуметтік әл-ауқатын көрсетеді.

Түйін сөздер: Қазақстан Республикасы, халықтың өмір сүру сапасы, әлеуметтік көрсеткіштер, өңірлердің типологиясы, негізгі индикаторлар.

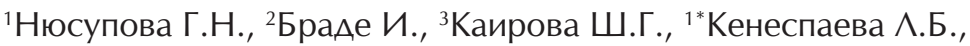 \\ 'Институт региональной географии имени Аейбница, Германия, г. Аейпциг \\ Павлодарский государственный универститет им. С.Торайғырова, Казахстан, г. Пав^одар \\ ${ }^{3}$ Казахский национальный университет имени аль-Фараби, \\ Казахстан, г. Алматы, e-mail: laura.kenespaeva81@gmail.com

\section{Социальные показатели качества жизни населения} \\ Республики Казахстан: анализ и оценка
}

\begin{abstract}
Показатели уровня и качества жизни населения призваны отражать степень развития социально-экономических отношений в стране. Современное государство может развиваться только при условии, что его социальная и экономическая политика имеет своим ориентиром рост уровня и качества жизни граждан. В данной статье отражены социальные показатели качества жизни населения Республики Казахстан: были определены основные ключевые индикаторы социального блока качества жизни населения, проведен расчет интегральных индексов, на основании которых проведена типология регионов Казахстана по социальному блоку уровня качества жизни населения. Социальный блок показателей качества жизни населения по регионам PK в динамике представлен статистическими данными по таким подблокам, как образование; наука и инновации; здравоохранение; культура; безопасность; жилищные условия; социальная инфраструктура; социальное обеспечение, Аосуг и отдых. К^ючевыми индикаторами, характеризующие качество хизни населения по социальному блоку являются: совокупная доля охвата образованием населения в возрасте 6-24 г.; индекс реальных денежных Аоходов населения; обеспеченность врачами; обеспеченность населения жильем; численность получателей государственных социальных пособий. Эти ключевые социальные индикаторы отражают социальное самочувствие населения в регионах.

Ключевые слова: Республика Казахстан, качество жизни населения, социальные показатели, типология регионов, ключевые индикаторы.
\end{abstract}

\section{Introduction}

Improving the quality of life of the population is the most important task of the social and economic policy of the state. The state policy of the Republic of Kazakhstan is defined as socially oriented, aimed at the long-term development of qualitative indicators of the population's life. To achieve this, the state develops and implements many state development programs: "Strategic Development Plan of the Republic of Kazakhstan until 2020", Strategy "Kazakhstan-2050": a new political course of the established state", Message from the President on October 5, 2018 "Growth of Welfare Kazakhstan people: raising incomes and quality of life", etc.

Quality of life is recognized by the international community as one of the main indicators characterizing the level of development of countries. The search for new ways of economic development has led to the realization that only the quality of life can most express the goals of the world community, because the humanity is on the way of transition to a new civilization - "quality civilization".

Quality of life is a broad and multifaceted concept and should be considered in four aspects: eco- nomic, demographic, social and environmental. It includes not only the level of consumption of material goods and services (standard of living), but also health, life expectancy, the state of the environment, etc.

The existing objective difficulties in the measurement and comprehensive assessment of the quality of life are due to the fact that the quality of life covers directly or indirectly almost all spheres of human activity, many of which cannot be quantified. Until now, the scientific community has not developed generally accepted set of indicators for an objective assessment of the quality of life.

One of the many approaches to assessing the quality of life is an economic approach. It uses to analyze social indicators of quality of life. Social indicators are often described as "statistical structures based on observations, usually quantitative that give us an idea of a certain aspect of social life" (Kordos, 1990). However, not all data obtained from statistical and sociological surveys can be used as social indicators.

A social indicator can be as objective indicators reflecting the position associated with a specific aspect of public life, and which indicates changes in 
this position, as well as subjective indicators showing how various segments of the population consider the objective position (or its change). Using subjective indicators, you can provide independent assessments of people participating in the study. These assessments depend on the individual value system.

Geographical approach to quality of life research is indispensable. Geographical science considers the quality of life as an integral phenomenon, determined by many factors, namely human health, economic, social, political, environmental, and natural and other conditions of his life, as well as the subjective assessment of the individual of various aspects of his life. It should be noted that the geographical approach to the definition of the quality of life differs from others in that geographers, in addition to the social and economic sphere, distinguish the environment as one of the fundamental factors in shaping the quality of life of the population.

\section{Material and methods}

The informational basis of the work was statistical and stock materials of the Committee of Statistics of the Republic of Kazakhstan using the system, analytical, comparative-geographical methods. The linear scaling method for calculating indices of quality of life of the population used in calculating the human development index, based on determining reference points (maximum and minimum values of indicators) and thus shows the real location of the indicator of each specific region between do them. The scoring method: as reference standards or standards can be selected: the maximum or average value of this indicator for a specific region or place; the actual value of this indicator for the base period (previous year, any other period); rational norm reflected in regulatory and legal documents.

\section{Results and discussion}

The works of geographers have enriched the existing methods of quality of life with their complexity, spatial aspect of the study. It should be noted that geographers used a combination of objective and subjective approaches to assessing the quality of life of the population.

From the position of social and economic geography, quality of life is one of the key categories that allows you to measure the social, economic and environmental performance of territories. Social and economic systems include the specifics of the life values of the population of a particular territory, satisfaction with life in general and its individual elements, resources of territories, living conditions of people, etc (Ostasiewicz, 2004; Ruževičius, 2014:
28). As a structural concept, quality of life includes the quality of the population (demographic characteristics, health, education), the quality of the living environment (natural and environmental conditions, the economic development of the territory, the development of social infrastructure, the level of personal safety senses) and the quality of the population's activities (labor, leisure, everyday life, spiritual, cultural and social and political) (Jankowska, 2014: 5; Marcel, 2014: 167).

Russian economic geographers, such as the founder of population geography, R.M. Kabo, the founder of economic geography, N.N. Baransky and others suggested the need to study the territorial differences in the way people live. As it can be seen from research, in the 60-70s of the 20th century the very concept of "quality of life" was not directly used in the works of Soviet geographers.

Modern Russian geographers in their research offer their own definitions and methods for assessing the quality of life, analyze the quality of life of the population in individual regions of the Russian Federation, various types of settlements, and give practical recommendations for improving the quality of life in individual territorial entities.

Along with the ecological and geographical approaches to the study of quality of life, individual researchers allocate epy separately synthesizing ecological-geographical approach based on the following positions that the factors and indicators of differentiation of the living environment affect the quality characteristics of the population, primarily health and quality of life.

Kazakhstan scientists in the field of economics, sociology, ecology and other sciences researched various aspects of the problems of the quality of life of the population. However, the geographical approach to assessing the quality of life is poorly represented by domestic geographers (National Atlas of the Republic of Kazakhstan, 2010).

Proceedings on the assessment of habitat quality can be found in researches of A.Zh. Abilov (Abilov, 2013: 142). In the researches of Sh.M. Nadyrov the problems of the spatial organization of the territory of the Republic of Kazakhstan and quality of life of the population of Kazakhstan inclusively are considered (Nadyrov, 2008: 300). In the doctoral thesises of E.Zh. Imashev and B.V. Shkurinsky the separate socio-geographical, economic-geographical, environmental-geographical indicators of the West Kazakhstan region are considered (Imashev, 2011; Shkurinsky, 2014: 35).

In the scientific works of G.N. Nyussupova and her PhD students A.M. Kalimurzina and G.K. Kai- 
ranbayeva quality of life and its various indicators are considered from the point of view of territorial differences at the macro-, meso- and microlevels (Nyussupova, 2011: 75).

In the scientific project "Development and creation of an electronic atlas of socio-demographic development of the regions of the Republic of Kazakhstan using GIS technology and information protection" under the supervising of G.N. Nyussupova a detailed analysis of socio-demographic indicators of the quality of life is conducted and the atlas of the socio-demographic development of the Republic of Kazakhstan is created (Nyussupova, 2015).

In this project, the key indicators that characterize the quality of life of the population of the regions of the Republic of Kazakhstan are selected to calculate the integral indices of social indicators. The social block of indicators of the quality of life of the population of Kazakhstan by the regions in the dynamics presents by statistical data on 9 subblocks: education; science and innovation; health care; culture; security; living conditions; social infrastructure; social security, leisure and recreation. The key indicators characterizing the quality of the population's life in the social unit are: the cumulative education enrollment rate for the population aged 6-24; index of real incomes of the population; physicians per 10000 people; housing provision of the population; the number of recipients of state social benefits. These key social indicators reflect the social well-being of the population in the regions (Nyussupova, 2018; Atlas of socio-demographic development of the regions of the Republic of Kazakhstan).

For all the above-mentioned key indicators the calculation of indexes were made using the linear scaling method in the dynamics for 1999-2017. The linear scaling method is based on determining refer- ence points (maximum and minimum values of indicators) and shows the real location of key indicators of each specific region between them.

All key indicators of the quality of life of the population of the regions of the Republic of Kazakhstan for 1999, 2009, 2017. were correlated according to 5 types of quality of life: with a high level, with a level above average, with an average level, with a level below average, with a low level.

Carrying out a typology on key indicators of social indicators revealed that in 1999 the indicator of the cumulative share of education enrollment at the age of 6-24 years old was the highest in Almaty (90.4\%), the lowest figure was recorded in Astana (58.5), Almaty and Zhambyl regions (63.4\% and $63.7 \%$, respectively) (Information-analytical system "Taldau" of the Committee of Statistics of the Republic of Kazakhstan).

In 2009, the highest level of the total share of education coverage was recorded in Almaty (123.9\%) and Astana (88.2\%), and the lowest share was in Kostanay (66.8\%) and Almaty (61.3\%). and North Kazakhstan regions (60.2\%).

The analysis of the types of regions by the level of the cumulative share of education enrollment at the age of 6-24 years, from 1999 to 2009, showed that this indicator in Astana increased by $30 \%$. Since 2009, Almaty and Astana are leaders in this indicator. Also, the West Kazakhstan and Karaganda regions are included in the type of regions with an average level of the cumulative share of education enrollment. Kostanay, Almaty and North Kazakhstan regions are included in the type with a low level of this indicator.

In 2017, a high level of the cumulative share of educational attainment remains in Astana and Almaty, low rates - in Kostanay, Almaty and North Kazakhstan regions (Table 1).

Table 1 - Typology of the regions of the Republic of Kazakhstan by the level of the cumulative share of education coverage of the population aged 6-24

\begin{tabular}{|c|c|c|c|}
\hline \multirow{2}{*}{$\begin{array}{c}\text { Types of regions with the } \\
\text { level of aggregate education } \\
\text { enrollment }\end{array}$} & 1999 & 2009 & 2017 \\
\cline { 2 - 4 } & Almaty & $\begin{array}{c}\text { Almaty } \\
\text { Astana }\end{array}$ & $\begin{array}{c}\text { Almaty } \\
\text { Astana }\end{array}$ \\
\hline With high level & Higher than 0,90 & Higher than 0,85 & Higher than 0,85 \\
\hline Index Range & $\begin{array}{c}\text { Aktobe; Mangystau; } \\
\text { Atyrau; West Kazakhstan; }\end{array}$ & $\begin{array}{c}\text { Mangystau; West Kazakhstan; } \\
\text { Karaganda }\end{array}$ & $\begin{array}{c}\text { West Kazakhstan; } \\
\text { Karaganda; }\end{array}$ \\
\hline Higher than average & $0,70-0,90$ & $0,75-0,85$ & $0,75-0,85$ \\
\hline
\end{tabular}


Social indicators of the quality of life of the population of the Republic of Kazakhstan: analysis and evaluation

\begin{tabular}{|c|c|c|c|}
\hline Average level & $\begin{array}{c}\text { Karaganda; } \\
\text { Pavlodar; }\end{array}$ & $\begin{array}{c}\text { South Kazakhstan; } \\
\text { Atyrau; } \\
\text { Aktobe }\end{array}$ & $\begin{array}{c}\text { Aktobe; Zhambyl } \\
\text { South Kazakhstan; } \\
\text { Akmola; Atyrau; }\end{array}$ \\
\hline Index Range & $0,68-0,70$ & $0,71-0,75$ & $0,71-0,75$ \\
\hline Below average & $\begin{array}{c}\text { Kyzylorda; Akmola; } \\
\text { East Kazakhstan; South } \\
\text { Kazakhstan; } \\
\text { North Kazakhstan; Kostanay; }\end{array}$ & $\begin{array}{c}\text { East Kazakhstan; Zhambyl; } \\
\text { Pavlodar; Kyzylorda; } \\
\text { Akmola }\end{array}$ & $\begin{array}{c}\text { Mangystau; Pavlodar; } \\
\text { East Kazakhstan; Kyzylorda; }\end{array}$ \\
\hline Index Range & $0,65-0,68$ & 0,67 - 0,71 & $0,67-0,71$ \\
\hline Low level & Zhambyl; Almaty; Astana & $\begin{array}{c}\text { Kostanay; Almaty; North } \\
\text { Kazakhstan; }\end{array}$ & $\begin{array}{c}\text { Kostanay; Almaty; North } \\
\text { Kazakhstan; }\end{array}$ \\
\hline Index Range & below 0,65 & below 0,67 & below 0,67 \\
\hline
\end{tabular}

Conducting a typology of the regions of $\mathrm{Ka}$ zakhstan in terms of the index of real incomes of the population revealed that in 1999 the highest indicator was recorded in West Kazakhstan (129.7), Almaty (177.6), Mangystau (117.2), Zhambyl (114.7) regions and in Almaty (116.6). Low indices of the population's real income in 1999 were in Karaganda (104.4) and in East Kazakhstan regions (101.0).

In 2009, there was a decrease in the index of real incomes of the population in all regions of Kazakhstan. The highest rates were mentioned in the North Kazakhstan (106.0) and Zhambyl regions (105.7), and low rates - in Aktobe (90.6) and Mangystau regions (84.6).

The analysis of the types of regions by the level of the index of real incomes of the population revealed that in the period from 1999 to 2017, the Karaganda and East Kazakhstan regions from the type with a low level of this indicator turned into the type above the average. In 2017, the Mangystau and South Kazakhstan regions were included in the type of regions with a low level of the index of real incomes of the population among the regions of the Republic of Kazakhstan (Table 2).

Table 2 - Typology of the regions of the Republic of Kazakhstan by indices of real money incomes of the population

\begin{tabular}{|c|c|c|c|}
\hline \multirow{2}{*}{$\begin{array}{l}\text { Types of regions with the } \\
\text { level of real incomes of the } \\
\text { population }\end{array}$} & \multicolumn{3}{|c|}{ Years } \\
\hline & 1999 & 2009 & 2017 \\
\hline High level & West Kazakhstan & $\begin{array}{c}\text { North Kazakhstan } \\
\text { Zhambyl }\end{array}$ & $\begin{array}{c}\text { Atyrau } \\
\text { East Kazakhstan }\end{array}$ \\
\hline Index Range & Higher than 0,7 & Higher than 0,4 & Higher than 0,46 \\
\hline Higher than average & $\begin{array}{c}\text { Almaty } \\
\text { Mangystau } \\
\text { Almaty city; Zhambyl }\end{array}$ & $\begin{array}{l}\text { West Kazakhstan } \\
\text { Akmola; Astana } \\
\text { Kyzylorda } \\
\text { East Kazakhstan }\end{array}$ & $\begin{array}{l}\text { Karaganda } \\
\text { Zhambyl } \\
\text { Aktobe } \\
\text { Kostanay }\end{array}$ \\
\hline Index Range & $0,57-0,7$ & $0,3-0,4$ & $0,42-0,46$ \\
\hline Average level & $\begin{array}{c}\text { South Kazakhstan } \\
\text { Aktobe; Kyzylorda } \\
\text { Astana }\end{array}$ & $\begin{array}{c}\text { Karaganda } \\
\text { Atyrau } \\
\text { South Kazakhstan }\end{array}$ & $\begin{array}{l}\text { Astana; North Kazakhstan } \\
\text { Akmola; West Kazakhstan }\end{array}$ \\
\hline Index Range & $0,5-0,57$ & $0,26-0,3$ & $0,35-0,42$ \\
\hline Below average & $\begin{array}{l}\text { Atyrau; North Kazakhstan } \\
\text { Pavlodar; Akmola } \\
\text { Kostanay }\end{array}$ & $\begin{array}{l}\text { Kostanay; Pavlodar } \\
\text { Almaty city; Almaty }\end{array}$ & $\begin{array}{l}\text { Pavlodar; Kyzylorda } \\
\text { Almaty; Almaty }\end{array}$ \\
\hline Index Range & $0,43-0,5$ & $0,2-0,26$ & $0,25-0,35$ \\
\hline Low level & $\begin{array}{c}\text { Karaganda } \\
\text { East Kazakhstan }\end{array}$ & $\begin{array}{l}\text { Aktobe } \\
\text { Mangystau }\end{array}$ & $\begin{array}{c}\text { Mangystau } \\
\text { South Kazakhstan }\end{array}$ \\
\hline Index Range & below 0,43 & below 0,2 & below 0,25 \\
\hline
\end{tabular}


The typology of the regions of Kazakhstan in terms of physicians per 10,000 people showed that in 1999 the type of level of regions with a high rate included Almaty (74.8 per 10 thousand people) and Astana (67.3 per 10 thousand people). Moreover, low rates were noted in Karaganda (24.4 per 10 thousand people), North Kazakhstan (23.3 per 10 thousand people) and Almaty (20.7 per 10 thousand people) regions.
In 2009 and 2017, the type of regions with a high level of physicians per 10,000 people included Almaty and Astana, exceeding the national average by 2 times. Karaganda region has moved to the type of regions with a higher average level. The regions with a low level of physicians per 10,000 people from 1999 to 2017 remain Almaty (23.3 per 10 thousand people) and Kostanay (26.6 per 10 thousand people) regions (Table 3 ).

Table 3 - Typology of regions of the Republic of Kazakhstan on the level of physicians per 10000 people

\begin{tabular}{|c|c|c|c|}
\hline \multirow{2}{*}{$\begin{array}{l}\text { Types of regions with level of } \\
\text { physicians per people } 10,000 \\
\text { people }\end{array}$} & \multicolumn{3}{|c|}{ Years } \\
\hline & 1999 & 2009 & 2017 \\
\hline With a high level of Almaty & $\begin{array}{l}\text { Astana } \\
\text { Almaty }\end{array}$ & $\begin{array}{l}\text { Astana } \\
\text { Almaty }\end{array}$ & $\begin{array}{l}\text { Astana } \\
\text { Almaty }\end{array}$ \\
\hline Range index & over 0,600 & over 0,600 & over 0,600 \\
\hline With level above an average & $\begin{array}{l}\text { West Kazakhstan } \\
\text { The South Kazakhstan } \\
\text { Aktobe; Kyzylorda }\end{array}$ & $\begin{array}{l}\text { Aktobe; Karaganda; } \\
\text { East Kazakhstan; } \\
\text { Pavlodar; Mangystau }\end{array}$ & $\begin{array}{l}\text { Karaganda; Aktobe } \\
\text { East Kazakhstan }\end{array}$ \\
\hline Index range & $0,2-0,6$ & $0,2-0,6$ & $0,3-0,6$ \\
\hline With the average level & $\begin{array}{c}\text { Pavlodar } \\
\text { East Kazakhstan }\end{array}$ & $\begin{array}{c}\text { Kyzylorda } \\
\text { The West Kazakhstan } \\
\text { Atyrau }\end{array}$ & $\begin{array}{c}\text { Kyzylorda; Mangystau } \\
\text { The West Kazakhstan } \\
\text { The South Kazakhstan; } \\
\text { Pavlodar }\end{array}$ \\
\hline Index range & $0,13-0,2$ & $0,13-0,2$ & $0,15-0,3$ \\
\hline With level below an average & $\begin{array}{c}\text { Kostanay; Atyrau } \\
\text { Akmola; Mangystau } \\
\text { Zhambyl Akmola; South } \\
\text { Kazakhstan } \\
\text { Zhambyl }\end{array}$ & $\begin{array}{l}\text { Akmola; South Kazakhstan } \\
\text { Zhambyl; North Kazakhstan } \\
\text { Kostanay }\end{array}$ & $\begin{array}{l}\text { North Kazakhstan; } \\
\text { Akmola; Atyrau } \\
\text { Zhambyl; Kostanay }\end{array}$ \\
\hline Index range & $0,060-0,13$ & $0,050-0,13$ & $0,050-0,15$ \\
\hline With the low level & $\begin{array}{c}\text { Karaganda } \\
\text { The North Kazakhstan } \\
\text { Almaty }\end{array}$ & Almaty & Almaty \\
\hline Index range & lower than 0,060 & lower than 0,050 & lower than 0,050 - \\
\hline
\end{tabular}

The analysis of the types of regions of the Republic of Kazakhstan in terms of housing provision showed that in 1999 the high rates were in Pavlodar (20.2 square meters per person), Karaganda (20.0 square meters per person) and Kyzylorda (19.1 square meters per person) regions. Low rates were in South Kazakhstan (13.8 square meters per person) and Kostanay regions (13.8 square meters per person).

In 2009, the regions with high housing provision were Astana (21.5 square meters per person), Karaganda region (21.3 square meters per person) and Pavlodar (20.7 square meters per person) regions.
The low level of housing provision was recorded in Mangystau (15.8 square meters per person), Zhambyl (15.7 square meters per person) and Almaty (15.6 square meters per person) regions.

Analysis of the types of regions in terms of the level of housing provision for the years 19992017 showed that there is a positive trend in the republic. The type with a high level of housing provision of population includes the cities of Almaty and Astana. Since 2009, their indicators have increased and in 2017, the indicator of housing provision exceeded the national average by 8 square meters per person. Almaty region (18.5 
square meters per person) and Zhambyl region (16.3 square meters per person) were included in the type of regions with a low level of housing supply (Table 4).

Table 4 - Typology of regions of the Republic of Kazakhstan on the level of housing provision of the population

\begin{tabular}{|c|c|c|c|}
\hline \multirow{2}{*}{$\begin{array}{l}\text { Types of regions with level } \\
\text { security of the population with } \\
\text { housing }\end{array}$} & \multicolumn{3}{|c|}{ Years } \\
\hline & 1999 & 2009 & 2017 \\
\hline With high level & $\begin{array}{l}\text { Pavlodar; Karaganda } \\
\text { Kyzylorda }\end{array}$ & $\begin{array}{l}\text { Astana; Karaganda } \\
\text { Pavlodar }\end{array}$ & $\begin{array}{l}\text { Astana } \\
\text { Almaty }\end{array}$ \\
\hline Index range & over 0,35 & over 0,45 & over 0,70 \\
\hline With level above an average & $\begin{array}{c}\text { The North Kazakhstan } \\
\text { Almaty } \\
\text { Akmola }\end{array}$ & $\begin{array}{c}\text { The North Kazakhstan } \\
\text { Kostanay region } \\
\text { Almaty; Akmola } \\
\text { East Kazakhstan }\end{array}$ & $\begin{array}{c}\text { Karaganda; Mangystau } \\
\text { Pavlodar; Akmola } \\
\text { Kostanay; Aktobe }\end{array}$ \\
\hline Index range & $0,25-0,35$ & $0,35-0,45$ & $0,50-0,70$ \\
\hline With the average level & $\begin{array}{c}\text { East Kazakhstan } \\
\text { The West Kazakhstan } \\
\text { Aktobe }\end{array}$ & South Kazakhstan & The North Kazakhstan \\
\hline Index range & $0,13-0,25$ & $0,25-0,35$ & $0,45-0,50$ \\
\hline With level below an average & $\begin{array}{c}\text { Atyrau; Mangystau } \\
\text { Zhambyl } \\
\text { Almaty } \\
\text { Astana }\end{array}$ & $\begin{array}{c}\text { Aktobe } \\
\text { Kyzylorda } \\
\text { The West Kazakhstan } \\
\text { Atyrau }\end{array}$ & $\begin{array}{c}\text { Atyrau; } \\
\text { The West Kazakhstan } \\
\text { East Kazakhstan } \\
\text { Kyzylorda } \\
\text { The South Kazakhstan }\end{array}$ \\
\hline Index range & $0,050-0,13$ & $0,20-0,25$ & $0,35-0,45$ \\
\hline With low level & $\begin{array}{c}\text { The South Kazakhstan } \\
\text { Kostanay }\end{array}$ & $\begin{array}{c}\text { Mangystau; Zhambyl } \\
\text { Almaty }\end{array}$ & $\begin{array}{l}\text { Almaty } \\
\text { Zhambyl }\end{array}$ \\
\hline Index range & lower than 0.050 & lower than 0,20 & lower than 0,35 \\
\hline
\end{tabular}

The analysis of the types of regions of Kazakhstan in terms of the number of recipients of state social benefits revealed that in 1999, the South Kazakhstan (111,971 people) and Almaty $(75,527$ people) regions had a high level. The lowest level was in Mangystau (18,420 people) region and in Astana (15 831 people).

In 2009, South Kazakhstan (114 334 people) and Almaty (79 398 people) regions were among the regions with the highest rate of recipients of state social benefits. Low rates were in Atyrau (20 762 people), Mangystau (20 139 people) regions and in Astana (17 609 people).

Analysis of the types of regions by the level of recipients of state social benefits for 1999-2017 showed that the number of recipients of social benefits is growing in the republic. The type of regions with a high level of recipients of social benefits include Almaty, Karaganda and South Kazakhstan regions. The type of regions with a low level of recipients of state social benefits include West Kazakhstan, Mangystau regions and Astana (Table 5).

Table 5 - Typology of regions of the Republic of Kazakhstan on the level of recipients of the welfare social benefits

\begin{tabular}{|c|c|c|c|}
\hline \multirow{2}{*}{$\begin{array}{l}\text { Types of regions with the } \\
\text { level of recipients of the } \\
\text { welfare social benefits }\end{array}$} & \multicolumn{3}{|c|}{ Years } \\
\hline & 1999 & 2009 & 2017 \\
\hline With high level & $\begin{array}{c}\text { South Kazakhstan } \\
\text { Almaty }\end{array}$ & $\begin{array}{c}\text { South Kazakhstan } \\
\text { Almaty }\end{array}$ & $\begin{array}{l}\text { South Kazakhstan } \\
\text { Almaty; Karaganda }\end{array}$ \\
\hline
\end{tabular}


Nyussupova G.N. et al.

\begin{tabular}{|c|c|c|c|}
\hline Index range & over 0,5 & over 0,5 & over 0,4 \\
\hline $\begin{array}{l}\text { With level above an } \\
\text { average }\end{array}$ & $\begin{array}{l}\text { East Kazakhstan } \\
\text { Karaganda } \\
\text { Zhambyl }\end{array}$ & $\begin{array}{l}\text { Karaganda } \\
\text { East Kazakhstan } \\
\text { Zhambyl }\end{array}$ & $\begin{array}{l}\text { East Kazakhstan } \\
\text { Zhambyl } \\
\text { Almaty }\end{array}$ \\
\hline Index range & $0,2-0,5$ & $0,2-0,5$ & $0,2-0,4$ \\
\hline With the average level & $\begin{array}{c}\text { Almaty; Kostanay } \\
\text { Akmola; North Kazakhstan } \\
\text { Kyzylorda; Pavlodar }\end{array}$ & $\begin{array}{l}\text { Almaty; Kostanay } \\
\text { Kyzylorda; } \\
\text { Akmola }\end{array}$ & $\begin{array}{l}\text { Kyzylorda; Kostanay } \\
\text { Aktobe; Akmola }\end{array}$ \\
\hline Index range & $0,13-0,2$ & $0,13-0,2$ & $0,12-0,2$ \\
\hline $\begin{array}{l}\text { With level below an } \\
\text { average }\end{array}$ & $\begin{array}{l}\text { West Kazakhstan } \\
\text { Aktobe } \\
\text { Atyrau }\end{array}$ & $\begin{array}{c}\text { North Kazakhstan; Pavlodar; } \\
\text { Aktobe; } \\
\text { West Kazakhstan }\end{array}$ & $\begin{array}{c}\text { Pavlodar; Astana } \\
\text { Mangystau; North Kazakhstan }\end{array}$ \\
\hline Index range & $0,050-0,13$ & $0,090-0,13$ & $0,091-0,11$ \\
\hline With low level & $\begin{array}{l}\text { Mangystau } \\
\text { Astana }\end{array}$ & $\begin{array}{l}\text { Astana; Atyrau } \\
\text { Mangystau }\end{array}$ & $\begin{array}{c}\text { West Kazakhstan Astana } \\
\text { Atyrau }\end{array}$ \\
\hline Index range & lower than 0,050 & lower than 0,060 & lower than 0,091 \\
\hline
\end{tabular}

\section{Conclusion}

According to the results of the typology of the regions by social indicators it was revealed that there is an improvement in the social status of the population in the whole republic. Since 1999, there has been an increase in the total share of education coverage by $4.4 \%$, reaching in $201771.5 \%$.

Analysis of the types of regions by the level of the index of real incomes of the population revealed that in the period from 1999 to 2017, the Karaganda and East Kazakhstan regions from the type with a low level of this indicator turned into the type above the average. Mangystau and South Kazakhstan regions in 2017 entered to the type of regions with a low level of the index of real incomes of the population among the regions of the Republic of Kazakhstan

In 2009 and 2017, the type of regions with a high level of physicians per 10000 people included Almaty and Astana cities, exceeding the national average by 2 times. Karaganda region has moved to the type of regions with a higher average level. The regions with a low level of physicians per 10000 people from 1999 to 2017 remain the Almaty and Kostanay regions.

According to the level of provision of the population with housing provision for 1999-2017 showed that there is a positive trend in the republic. The type with a high level of housing provision of population includes Almaty and Astana cities. Since 2009, their indicators have increased and in 2017 in these cities the housing provision index exceeded the national average by 8 sq.m. per person. The type of regions with a low level of housing provision included Almaty and Zhambyl regions. The housing provision of the population increased from 16.4 sq.m. per person in 1999 to 21.4 sq.m. per person in 2017

According to the level of recipients of state social benefits for 1999-2017 this indicator is growing in the republic. The type of regions with a high level of recipients of social benefits include Almaty, Karaganda and South Kazakhstan regions. The type of regions with a low level of recipients of state social benefits include the West Kazakhstan, Mangystau regions and Astana.

Kazakhstan has proclaimed a policy of building a welfare state with high standards of living. This position is reflected in the messages of the head of state. This is confirmed by the current Message of the President "Growth of the welfare of Kazakhstanis: improving incomes and the quality of life", which is a sustainable strategy for improving the quality of life of Kazakhstan people (N.Nazarbayev, 2018). The core of the Message has become a social theme. The President of Kazakhstan stressed that the state fulfills all of its social obligations, provides salary increases, and takes measures to solve the housing problem. 


\section{References}

Sotsial'nyye indikatory Respubliki Kazakhstan. Atlas social'no-demograficheskogo razvitija regionov Respubliki Kazahstan [Atlas of socio-demographic development of the regions of the Republic of Kazakhstan] http://atlassd.kaznu.kz/ Last accessed 20 November 2018.

Ewa Jankowska (2014). Social indicators and the measure of the quality of life. Torun Internatonal Studies. No. 1 (70), pp. 5-13 Informatsionno-analiticheskaya sistema «Taldau» Komiteta statistiki Respubliki Kazakhstan [Information-analytical system "Taldau" of the Committee of Statistics of the Republic of Kazakhstan] available at https://taldau.stat.gov.kz/ru. Last accessed 25 November 2018.

Imashev E.Zh. (2011) Tendencii i prioritety prostranstvennogo razvitija Zapadno-Kazahstanskoj oblasti. Avtoreferat na soiskanie stepeni kandidata geograficheskih nauk [Trends and priorities of the spatial development of the West Kazakhstan region. Abstract for the degree of candidate of geographical sciences], Ufa, p. 38

Juozas Ruževičius (2014). Quality of Life and of Working Life: Conceptions and Research. 17th Toulon-Verona International Conference. Liverpool John Moores University. Liverpool (England). Conference Proceedings, August 28-29,

Marcel W.M. (2014) Definitions of Quality of Life: What Has Happened and How to Move On. Top Spinal Cord Inj Rehabil. Summer; 20(3), pp. 167-180.

Nacional'nyj atlas Respubliki Kazahstan. Tom 2: Social'no-jekonomicheskoe razvitie [National Atlas of the Republic of Kazakhstan. Volume 2: Socio-Economic Development]. Almaty, 2010, 164 p.

Nyussupova G. (2015). Otchet o nauchno-issledovatel'skoj rabote «Razrabotka i sozdanie jelektronnogo atlasa social'no-demograficheskogo razvitija regionov Respubliki Kazahstan s ispol'zovaniem tehnologii GIS i zashhity informacii» (godovoj) [Report on the research work "Development and creation of an electronic atlas of socio-demographic development of the regions of the Republic of Kazakhstan using GIS technology and information protection" (annual). Almaty, $105 \mathrm{p}$.

Nyussupova G., Rodionova I. (2011) Demographic Situation and the Level of Human Development of the Republic of Kazakhstan: Regional Aspects // Bulletin of Geography. Socio-economic Series. № 16 (16), p. 75-87

Nyussupova G.N., Sarsenova I.B. (2012) Modern demographic processes in the cities of the Republic of Kazakhstan. American International Journal of Contemporary Research (AIJCR).-New York, vol.2 №7, July, p.239-244

Nyussupova, G., Kenespaeva, L., Karagulova, R., Saginbay, O., Aidarkhanova, G. (2018) Socio-demographical indicators of an electronic atlas of socio-demographic development of the regions of the republic of Kazakhstan (2018) International Multidisciplinary Scientific GeoConference Surveying Geology and Mining Ecology Management, SGEM, 18 (2.3), pp. 559-566. SJR=0.211.

Poslanie Prezidenta Respubliki Kazahstan N.Nazarbaeva narodu Kazahstana: Rost blagosostojanija kazahstancev: povyshenie dohodov i kachestva zhizni. 5 oktjabrja 2018 g. [Message of the President of the Republic of Kazakhstan N.Nazarbayev to the people of Kazakhstan: Growth of well-being of Kazakhstanis: increase of incomes and quality of life. October 5, 2018] http://www.akorda. kz/ru/addresses. Last accessed 20 November 2018.

Ofitsial'naya statisticheskaya informatsiya. Obrazovaniye. Sajt Komiteta po statistike Ministerstva nacional'noj jekonomiki Respubliki Kazahstan [Official statistical information. Education. Website of the Committee on Statistics of the Ministry of National Economy of the Republic of Kazakhstan] http://stat.gov.kz/faces/wcnav_externalId/homeNumbersEducation?_afrLoop=7744225184690663. Last accessed 15 November 2018.

Shkurinsky B.V. (2014) Mediko-geograficheskaja situacija v Zapadno-Kazahstanskoj oblasti. Avtoreferat na soiskanie stepeni kandidata geograficheskih nauk [Medico-geographical situation in the West Kazakhstan region. Abstract for the degree of candidate of geographical sciences], Perm, p. 35

Walenty Ostasiewicz (2004). Quality of Life Research Paperback. International conference on quality of life. $1 \mathrm{March} / \mathrm{https} / /$ www.springer.com/medicine/journal/11136 